\title{
On the obsolescence of human beings in sustainable development
}

DOI:

10.1080/23269995.2017.1300417

\section{Document Version}

Accepted author manuscript

Link to publication record in Manchester Research Explorer

\section{Citation for published version (APA):}

Ehgartner, U., Gould, P., \& Hudson, M. (2017). On the obsolescence of human beings in sustainable development. Global Discourse, 7(1), 66-83. https://doi.org/10.1080/23269995.2017.1300417

\section{Published in:}

Global Discourse

\section{Citing this paper}

Please note that where the full-text provided on Manchester Research Explorer is the Author Accepted Manuscript or Proof version this may differ from the final Published version. If citing, it is advised that you check and use the publisher's definitive version.

\section{General rights}

Copyright and moral rights for the publications made accessible in the Research Explorer are retained by the authors and/or other copyright owners and it is a condition of accessing publications that users recognise and abide by the legal requirements associated with these rights.

\section{Takedown policy}

If you believe that this document breaches copyright please refer to the University of Manchester's Takedown Procedures [http://man.ac.uk/04Y6Bo] or contact uml.scholarlycommunications@manchester.ac.uk providing relevant details, so we can investigate your claim.

\section{OPEN ACCESS}




\title{
Author Accepted Manuscript.
}

Submitted and accepted on 30.11.2016

\section{On the Obsolescence of Human Beings in Sustainable Development}

Authors: Ulrike Ehgartner, Patrick Gould and Marc Hudson

(Sustainable Consumption Institute, University of Manchester, Manchester, UK)

published version: Ehgartner, E., Gould, P. \& Hudson, M. (2017) On the obsolescence of human beings in sustainable development, Global Discourse, 7:1, pp. 66-83.

\begin{abstract}
In 1956 the Jewish-German philosopher Günther Anders developed a philosophical anthropology on the technological and moral challenges of his time. His major work, The Obsolescence of Human Beings, dealt with the years following the bombing of Hiroshima, when humankind for the first time in history grappled with the technological ability to entirely extinguish itself. Anders suggested the societal changes that arose with the industrial age, opened a gap between the capability of individuals to produce machines and their ability to imagine and deal with the consequences caused by this capability. A 'Promethean Gap' manifests in academic and scientific thinking and leads to the extensive trivialization of societal issues. Subsequently, human beings in the 'Age of the Third Industrial Revolution' are incapable of relating to the possibility of omnicide. Seventy years after the world first faced the threat of the nuclear bomb, the human race still exists and faces the imminent apocalypse of climate change. One way to combat the threat, are the recently launched UN Sustainable Development Goals (SDG), lauding aspects like green growth, climate-smart agriculture, emissions trade, eco-fuel and GM food. Anders' philosophical anthropology contributes substantially to a discussion of these and alike attempts to fight climate change with innovations. His description of 'apocalyptic blindness' is immanent in the ideas of sustainability the UN draws upon. Related narratives on ethical consumption demonstrate how humanity is caught up in a 'promethean shame' for not being able to do anything about the fact that we have not caused the outcomes of our actions. Anders helps us to explain why we cannot help pairing our belief in historical progress and growth with our ideas on social and environmental justice. With that said, this paper contributes to the debate on humanity 'after sustainability' by calling to mind Anders' historical theory on the outdatedness of humankind and his thoughts on our lack of imagination.
\end{abstract}

Keywords: sustainability, development, ethical consumption, technology, promethean shame, apocalyptic blindness 
'And how do we respond to it?

Just in the same way we respond to newspaper reports: not at all.

And why do we not react? Out of courage? Out of stoicism? [...]

Out of the lack of imagination. Because we are apocalyptically blind.'

- $\quad$ Günther Anders (1961 [1956], 263) ${ }^{1}$

\section{Introduction}

Sustainability is dead. Long live sustainability. Since the 1970 's, crisis has been the defining theme for environmentalists. Biodiversity crisis; oil crisis; nuclear crisis; drought crisis; flood crisis; warming crisis; extinction crisis - a multitude of crises coalescing in a 'nexus' of threats. As such, visions of the apocalypse, and 'end-times', have come to form another central component for the environmental movement. The underlying critique of late capitalist society has been 'If we carry on this way, the world as we know it will be destroyed.' Indeed, visions and predictions of judgment and apocalypse are not new phenomena; but what has interested scholars of environmental history is the specific representation and identification of the apocalypse in contemporary Western society around climate change (Buell 2003; Young and Barr 2014).

But what if the apocalypse or end-time was not some point over the horizon, a future event yet to be experienced, but what if it was now, in this moment? This idea, a realignment of the apocalypse to envelope the present, to take our gaze away from the past and future and develop an understanding and philosophy of the present were the central ideas of Günther Anders. Not another obscure German philosopher we hear you cry. But what is peculiar about Anders' relative anonymity in English-speaking academic work is his importance and standing in German speaking scholarship, where his stature was gained through his philosophies on technology, environmental politics and culture (Liessmann 2002; Bahr 2012; Dries 2014).

This article seeks to contribute to existing moves that 'close the case' on the sustainable development paradigm (Foster 2015; Benson and Craig 2014). Through the lens of Günther Anders' main ideas, promethean shame and apocalyptic blindness, this article suggests ways of developing a 'post-sustainability' approach to include a more robust understanding of how we may come to frame and understand widespread denial and confusion in 'Endzeit' (End-time) and 'Zeitende' (Endof-Time).

\footnotetext{
${ }^{1}$ All quotations of Anders' German contributions used in this paper $(1961,1964,1981,2002)$ have been translated by the author.
} 
The first section of this article frames Anders' main positions and perspectives in relation to international policies surrounding sustainability and economic development. Locating Anders in the academic landscape with reference to his personal and philosophical history, the recently agreed UN Sustainable Development Goals (SDGs) will be discussed.

This will bring the discussion on to two more salient developments in sustainability: sustainable consumption and the citizen-consumer. Again these will be explored and investigated through Anders' main philosophical contributions, giving way to a more general outline on the morality of economic liberalism in Western societies.

Finally, we will argue that bringing Anders' philosophical anthropology into play will help us to understand that the 'sustainability' paradigm has failed. We argue that developing a philosophy of the present through education and personal morality to end the 'promethean shame' of our current malaise can aid research and understandings on the difficulties and possibilities of a world after sustainability.

\section{Condemned to freedom}

Given that a special issue of this journal is dedicated to exploring themes around denial, sustainability and climate change, the growing interest in Anders' work in Anglophone countries ${ }^{2}$ provides particular purchase to explore these issues. Born in 1902, the consequences of the industrial revolution as well as the catastrophes of the twentieth century were crucial aspects in Günther Anders' life. While Hiroshima and the nuclear threat are at the core and probably the most obviously influential historical conditions of Anders writing, events such as Auschwitz and the Vietnam War, as well as his life periods in exile in France and the USA crucially influenced Anders' thinking and provided the key element of his philosophical anthropology (Bahr 2012; Van Dijk 2000). Given his positioning - historically, as well as intellectually - Anders can be aligned with many other intellectuals and activists of his time who expressed concerns about technology and popular culture and made the destructive potential of modern technology and the omnipresent potential for mass destruction the focal point of their historical, social and moral analyses. Nevertheless, it would be a disservice to the importance and influence of Anders' work to dismiss him as just another moralizing critic of modernization and technology. As Christopher Müller $(2015,44)$ argues in his recent mapping of what he calls 'desert ethics' - inaccessible spaces of human agency - 'it is to this attempt to think machines "differently" that Anders' reflections on the obsolescence of moral sentiments can make an important contribution.'

\footnotetext{
2 See e.g. Dawsey 2012 and 2013, Babich 2012, 2013a and 2013b, Müller 2015 as well as the recent translation of Anders' essay on 'The world as phantom and as matrix: philosophical considerations on radio and television,' as well as a complete translation of 'The Outdatedness of Human Beings 2.' available online (Libcom.org 2014, 2015).
} 
In postwar time, the vast impact of machines was widely welcomed in society, while various philosophers warned of their threats and consequences. Thus, in many ways, Anders reminds us of more famous contemporaries such as Lewis Mumford, Jacques Ellul or Norbert Wiener. ${ }^{3}$ However, Anders' thinking is notable for his persistence in recognizing the twentieth century not only as a new historical era, but as an 'endtime.' His prognostic hermeneutic of a world of machines (Anders 2002, 424-426) and his ability to argue that the reproduced reality reflects back on to the actual reality (Anders 1961, 165-170) are just a few aspects that should not be disregarded in contemporary research.

An early and significant moment in Anders' life was his lecture on 'The Unworldliness of the Human Being' in 1929, ${ }^{4}$ where he opposed the philosophical attempt to establish the essence of the human being as such. Carrying all anthropological questions on who or what human beings are to their grave, ${ }^{5}$ this moment of academic positioning can be marked as the beginning of Anders' life-long dispute with Heidegger. ${ }^{6}$ More than this, it can be claimed that this lecture marks out the moment Anders broke with academia. He could not return to Heidegger and Husserl and the Frankfurt School scholars followed another school of thought (Bahr, 2012).

Regardless of the formal consequences that Anders' early positioning on the essence of the human being might have had, it provided the foundations to his philosophical anthropology (Bahr 2012). Anders elaborated his perception of the human being by placing his philosophical anthropology within Nietzsche's animal that is not yet adapted to his environment (Nietzsche 1907, 82), when he argued that the course of conduct of human beings is not determined as it is for animals. ${ }^{7}$ Unlike animals, humans are not adjusted to the world they live in. Thus, they are not forced to follow a given path and given their promethean freedom, they have to find their own way and are,

\footnotetext{
${ }^{3}$ This is particularly evident for his analysis of the human being. Reading about the 'metamorphosis' in the industrial age (Anders 1961, 15-16), for example, inevitably provokes associations with Lewis Mumford's 'transformation' (1957).

${ }^{4}$ In German orig: 'Die Weltfremdheit des Menschen' (Liessmann 2002, 30-52). This speech is not available in German original. However, a French essay version based on this speech was published six years later ('Pathologie de la liberté. Essai sur la non-identification', 1936), of which there is an English translation available ('The Pathology of Freedom: An Essay on Non-Identification', 2009).

5 "For Anders, such attempts to separate and single out the human being from the aggregate of beings, and therefore all forms of anthropocentrism, are typical of the metaphysics of the Western world. Such an elevated position of the human being leads to degradation of all other beings to mere means and must ultimately lead to exploitation and destruction of nature" (Van Dijk, 2000, 102).

${ }^{6}$ Having been a student of Heidegger in his earlier life, he later on claimed that he had been fallen under his 'demonic spell' (Dries 2014). On Anders' standpoint to the question 'what is man' and his critique of Heidegger in that context see also Anders 2002, 128-130.

${ }^{7}$ Further to this anthropologist tradition, Anders could be denominated as Gehlens' antipode in the context of the twentieth century. Despite the similarities in both their analyses, Anders substantially distanced himself from the conservative anthropologist Gehlen, referring to his words as 'darkest provincialism' (Greffrath 1989, 48-50). On Gehlen and his explanations of the human as a deficient being (Mängelwesen), see Gehlen 1940.
} 
consequently, doomed for self-creation: '(A)rtificiality is the nature of man and his essence is instability' (Anders 2009, 279). ${ }^{8}$

As humans do not simply react to the world around them but are forced to make it theirs, they do not have to use the given resources only, but they can invent, produce and use things. Thus, they are free and they are not (Anders 1961, 15-16); they are, to put it in the famous words, 'condemned to freedom..$^{9}$ Anders argues that not humans are the subject of history in our times, but the machines that they created. Being in an inferior position in relation to machines, human beings have lost their freedom as they are forced to use and consume the machines' products (Bahr 2012; Liessmann 2002).

\section{We know but we cannot comprehend}

In late September 2015, falling leaves gathered in the drains and the gutters of New York City; a street cleaner busied along sweeping them into his black bag. Not far away, a similar exercise was taking place. In the conference hall of the UN, the upper echelon of suited global street cleaners ratified a set of seventeen Sustainable Development Goals (SDGs) to clear our world of detritus and decay by 2030 .

In the tradition of summits that date back to the 1972 Stockholm Conference on the Human Environment, major stakeholders took part in a widely discussed debate on sustainable development (Death 2015). Again, international agreements emphasize the importance of tackling the challenge of climate change. The agreements made both hold a reformist approach and have ambitious aims; being well aware of our own unsustainability, the urgency to radically change our ecological policies is being recognized.

However, these agreements carry either no legal obligations or weak ones with few, if any, enforcement mechanisms (Spash 2016). Facing societal and environmental change, we carry on as usual rely on technology that might or might not yet exist. All attempts for adaptation seek to defend, secure and reinforce our existing technological and managerial systems, not touching the mechanisms of the modern market economy (Blühdorn 2008, 2011, 2015). Even though we

\footnotetext{
${ }^{8}$ Anders' philosophical anthropology explains how humans are set to not look towards a certain end: If human history is made for experimenting and designing, there is no end of it to be seen (Anders 1961). The notion of humans being sacrificed to the demands of the machinic world, however, was current at the time. See Charlie Chaplin's ,Modern Times', in which he becomes quite literally a cog in the machine. See also Fritz Lang's dystopic 'Metropolis' for a similar account. Earlier, the English novelist E.M Forster wrote a short story, ,The Machine Stops' about humans who had become dependent upon machines for every aspect of their lives.

${ }^{9}$ Note that, even though it was Sartre, who adopted fundamental thoughts of this piece and made the quote of the man condemned to be free famous, it was Anders' who stated this claim about the human existence in his 'Pathology of Freedom' already 'a few years before Sartre', as emphasized by Anders (Anders 2002:130).
} 
acknowledge that the issue is serious, we are - in Anders' words - 'apocalyptically blind' (Anders 1961, 235-306).

'Apocalyptic blindness', according to Anders, is the mindset of humans in the age of the Third Industrial Revolution ${ }^{10}$; it determines a notion of time and future that renders human beings incapable of facing the possibility of a bad end to their history. The belief in progress, persistently ingrained since the Industrial Revolution (see also Popper 1957), causes the incapability of humans to understand that their existence is threatened, and that this could lead to the end of their history. ${ }^{11}$ We are unable to understand, because we have lost our ability to relate conduct and consciousness to the same matter. In other words: we face a gap between our ability to produce and our ability to imagine; a gap between knowledge and comprehension - a 'promethean gap' (Anders 1961).

Even though Anders is often referred to as a moralist, he did not attempt to reason morally, neither was he seeking to appropriate a new moral to the twentieth century. Essentially, he attempted to explain how technology and the division of labor eliminate morals, or more precisely, moral imagination. This is a crucial point, since Anders believed that it is ultimately the lack of moral imagination that made omnicide - the extermination of all life - not an unlikely event to happen. The lack of moral imagination becomes apparent in the way that processes of work consist of so many steps of various instances, so that none of these steps could be identified as the one step. Thus, in relation to the atomic bomb, in the end, no-one could be blamed for having caused the apocalypse (Anders 1961, 245).

According to Anders, it is the moral situation that determines whether we are able to comprehend a matter; whether something concerns us or not. ${ }^{12}$ There are numerous examples of matters which concern us, but subjectively they do not. We are concerned with issues such as oil spills, rising sea levels and the suffering caused by intensive animal husbandry. These are things we either may or may not comprehend; things we are excluded from interfering with, given the division of

\footnotetext{
${ }^{10}$ The first volume of Anders' major work was originally published in Germany in 1956, given the title: 'Die Antiquiertheit des Menschen. Über die Seele im Zeitalter der zweiten industriellen Revolution. [The Outdatedness of Human Beings 1. On the Soul in the Era of the Second Industrial Revolution].' This was followed by a second volume in 1980, titled 'Die Antiquiertheit des Menschen: Über die Zerstörung des Lebens im Zeitalter der dritten industriellen Revolution. [The Outdatedness of Human Beings 2. On the Destruction of Life in the Era of the Third Industrial Revolution].' In the second volume, Anders explains that epochs no longer change after 1945, as with the atomic bombing of Hiroshima notions of a continuation of history and a succession of other epochs became invalid. The current epoch, in any event, is the last one. The third revolution is, therefore, the last age of humanity (Anders 2002, 15-33).

${ }^{11}$ The faith in progress and the trust in new technological solutions to recurring issues define the thinking in the twentieth century, when nobody would think, as Heidegger (1976) had put it, that 'only a god can save us.'

${ }^{12}$ Though of course, social and financial benefits can accrue to those who are able not to see, a point made forcefully in pre-bomb literature such as Hans Christian Andersen's 'The Emperor's New Clothes' and Henrik Ibsen's 'An Enemy of the People.' For a more recent, and scholarly exposition of this, see Stanley Cohen's 'States of Denial: Knowing about Atrocities and Suffering' (2001)
} 
responsibilities, ownership structures and political forces. Anders says that if the possibility to create and command over matters is taken from us and we do not explicitly offer resistance, it will soon lose any real concern for us. We are blind to whatever we are forced to refrain from. ${ }^{13}$ It is not that we do not know. We know, but we do not comprehend. Therefore we carry on life as if we would not know (Anders 1961, 285-286).

\section{Universal Mechanization and the identity crisis}

Global mechanisms for bringing about environmental change and human progress have been on the UN's agenda since the late 1960s, and came to an early head at the United Nations Conference on the Human Environment in 1972 at Stockholm. In the midst of the Cold War, heightening concerns around nuclear war and environmental destruction prompted action on creating international treatise on the protection of the environment. ${ }^{14}$

As years passed and damage accumulated, the solution amongst policy makers and statesmen was ever greater integration through the global economy, and the construction of a universal mechanism that can bring about a more peaceful, just and sustainable world; in the famous words of the Brundtland Commission (1987), 'meeting the needs of the present without compromising the ability of future generations to meet their own needs'. The sustainability paradigm that emerged back then did recognize the limits to growth and the need for a shift of focus from western consumerist needs to global fundamental human needs and made, initially, no pretence of having a deep-rooted relation to environmental movements.

However, as soothing as the still well-cited words from the UN's early days sustainable agenda are for the 'soul' in our age (Anders 1961, 15), given the Zeitgeist of this age, they were - as Anders would undoubtedly say - never seriously considered to be more than symbolic statements. Aesthetic norms such as the preservation of the beauty of the nature, religious imperatives to protect divine creation and ethical principles to respect the integrity and dignity of nature (Blühdorn 2015, 158) are not applicable in a society in which humans are 'existing only as parts of machinery, or as parts of the material required by the machine' (Anders 1988, 53). The construction of a universal discourse around environmental sustainability is condemned to be paired with development plans based on principles and measures of science and economics.

The human being of the twentieth century, says Anders, manifests as a faulty piece of machinery within machines of a set design (Anders 1961, 32-34). The sustainable development paradigm has

\footnotetext{
${ }^{13}$ See in that context the existentialist thought on the self-deceiving attitude of humans and that '(b)ad faith...is a social disease rather than an individual failing, in Sartre's view, and is an ongoing condition rather than a sporadic activity' (Webber 2010, 188). Also note the more recent literature on 'willful blindness' in the context of short term economic interest (Heffernan 2011)

${ }^{14}$ For discussion see Howe 2014
} 
seen the continued functionalization of man, the subordination of human will to the will of the machine, a techno-totalitarian apparatus with 'the human being condemned to freedom' (Van Dijk $2000,29)$. The shift of responsibility to an entity that we constructed silences our last remaining call of consciousness. This entity is represented by electronic machines, the epitome of science and progress; with humankind right beside it - half grateful and half triumphant. Understanding that the machines are achieving better performances than ourselves, we accept that we are less competent and shift, consequently, the responsibility for the outcomes of actions on to the object. In that way, personal responsibility is replaced with mechanic 'responses' (Anders 1961, 246).

\section{Goals as Phantoms}

Anders' perspective on apocalyptic blindness rests on the future-orientated activities of man 'looking, listening and living away' (Anders 1961, 236). Nothing represents this view better than the creation of 'Goals' as a way to measure and achieve progress in global development and sustainability. In our inability to fear, ${ }^{15}$ the formulation of goals gives us hope that we are preparing aims for the future. In that way, we approach the historical catastrophe as a part of our history and are blind to its true meaning: signifying the end of our history and as such something that cannot go down in history (Anders 1961, 262-263). Despite our planning for the future, from 'the World in 2050 ' reports to pension schemes and frozen food, Anders argues we are always drawn back to the present and the future is always in a state of 'not yet' (Müller 2015, 53).

Replacing the Millennium Development Goals (MDGs) that expired at the end of 2015 amid controversy and debates over their effectiveness (Rieff 2015, 48-51); the SDGs provide seventeen antidotes to prescribe to a sick patient. Like an over-used New York taxi that has chugged its way to the garage, a band of mechanics gleefully wait with a toolbox in one hand and a card machine in the other. Except the planet is neither a human being nor a car. 'An immense industrial network cannot be managed', Georges Bataille $(1988,19)$ wrote of the Marshall Plan, 'in the same way that one changes a tire'.

When one reads through the 'Transforming our world: the 2030 Agenda for Sustainable Development' the level of scope and aspiration is considerable. From the 91 subsections, there are constant references to the ' 5 P's': People, Planet, Peace, Prosperity and Partnership. Yet there is something contradictory, careless and excessive about the number points and the topics they cover.

\footnotetext{
${ }^{15}$ Anders argues that anxiety got converted into a commodity. These days, he says, everybody speaks about anxiety, but just a few speak out of anxiety (Anders 1961, 264).
} 
The sheer number of aims and promotions can situate individuals in a quagmire of policy interventions - where to start? What to do? Like a child writing their Christmas list to Santa, the policy makers couldn't help themselves in just putting one or two more in. Here is a small selection:

"3.6 By 2020, halve the number of global deaths and injuries from road traffic accidents

4.4 By 2030, substantially increase the number of youth and adults who have relevant skills, including technical and vocational skills, for employment, decent jobs and entrepreneurship

12.8 By 2030, ensure that people everywhere have the relevant information and awareness for sustainable development and lifestyles in harmony with nature

14.b Provide access for small-scale artisanal fishers to marine resources and markets"

(UN 2015, 12-23)

For all the ensuring, committing, providing, aiming and ending, come 2030 where will we be? Making use of a jargon of consideration and ambition, the list of goals remains vague in declaring what the actual contents and means of their implementation would be. This indeterminacy, a goalattainment followed by another goal-attainment, is particularly relevant to Anders' view on our apocalyptic blindness. The 'End-time' we find ourselves in, an epoch of which there is no other to come, mobilizes the future only to blind us to its possibilities. The calculation of time is a product of the machine; through the setting of goals as a pillar of sustainable development that calculates the future as a concrete space, one that is set but at the same time in need of constant work and adaptation.

The SDGs 'will be voluntary and country-led...and will respect [national] policy space and priorities' (UN 2015, 27). Indeed, the SDGs are not ensured by any legal bindings or sanctions. This means that the UN will have to rely on self-commitments. Aiming to accomplish such a universalizing consensus, Ban Ki-Moon's idea on role allocation seems clear - 'Governments must take the lead in living up to their pledges'. At the same time, he is 'counting on the private sector to drive success' (Moon, 2015 [26 September]).

Based on the success of previous 'voluntary-led' and 'self-regulating' schemes, strategies, pacts, acts and goals should we be wary of such promises? The UN implores us not to be, for the SDGs are argued to take a different course from the MDGs in taking a 'people-centered' approach; that is, responsibility is for one and all - 'as we embark on this great collective journey, we pledge that no one will be left behind' (UN 2015, 2). The UN promises us that the SDGs are the blueprints, but we, 'the people', are the builders. Except, we are not. And this is the trick; the great sleight of hand of international development and progress. Behind the language of global responsibility, intra-species 
solidarity, and shared values exists a socio-technical apparatus grand in design yet unmoored from its consequences - that is, apocalyptically blind.

The language used in the context of sustainable development creates the idea that we are all complicit. Voluntary self-commitment should transform our 'unsustainable lifestyles' into 'more sustainable lifestyles.' The narrative that we are all part of it, that we, the majority of humans, wanted, planned and made it, however, is absurd; not only absurd, but dangerous. This perception only suits the unlucky ones who happen to be the immediate 'subjects' of the machines, who command over their production and application. Thus, talking about the 'suicide of mankind' provides an ideally broad basis for responsibility, a 'superb alibi', where everybody is virtually complicit but nobody immediately guilty (Anders 1961, 255-256).

\section{The (un-)sustainable consumer: Guilty of the lack of responsibility}

The horrifying character of the current situation of humankind, although it is our work, is not our fault. We can only perceive, as Benjamin famously wrote of Paul Klee's Angelus Novus 'a chain of events,' even though the Angel, looking at the same events 'sees one single catastrophe which keeps piling wreckage upon wreckage and hurls it in front of his feet' (Benjamin 1969, 257-258). Not only are we not culpable, but we are not even permitted to be culpable anymore. Being irresponsible for our own actions, humans find themselves as a 'miserable' resource: they are perishable - a product of nature, a body that is so rigid and un-free that it could never keep up with the changes of technology. Given that situation, the human being suffers from feelings of inferiority in the face of their machines (Anders 1961, 49-50). ${ }^{16}$

The twentieth century taught us to disregard the human being as an integrated whole, but separate the individual as an actor from its quality as a sentient being. ${ }^{17}$ Being all successors of a history of schizophrenic beings when one person could work for a death camp and be a loving father at the same time, Anders would argue, we certainly have a hard time to find a contradiction between doing a nine-to-five job to make a living and advocating for environmental and human rights issues. As both fragments are not related to each other, they are not getting in the way of each other (Anders 1961, 272).

In academic research, in policy papers, as well as in marketing strategies for sustainable consumption, it is often claimed that global social and environmental problems such as working conditions of farmers in the global south or children in textile factories are too abstract for our

\footnotetext{
${ }^{16}$ Perhaps Anders would see this continuation of 'universal mechanization' as an unavoidable tendency from the division of labour and specialisation in the late 18th century. This would be quite a deterministic interpretation of Anders' thoughts though, and while he was highly influenced by Marx's analysis of dialectical materialism, he also provides the space for the reclamation of the human 'soul' from the processes of modernisation and an eventual apocalypse.

${ }^{17}$ The similarity to Arendt's famous observation about the banality of evil is unmistakable (Arendt, 1963).
} 
imagination. Anders would agree with these findings in that our power for imagination does not stand up to the system of the global production of goods and the economic interrelation with the world. More importantly, however, he would ascribe the call for and implementation of sustainable consumption to the manifestation of promethean shame.

Dealing with sustainability, many businesses, policy makers, campaigners, lobbyists and academics, take the socially and environmentally caring consumer or citizen - or citizen-consumer (Sassatelli 2007; Trentmann 2007), as they are habitually called, building on the naïve faith in promethean freedom - as a matter of fact. Based on that, ways are explored to 'nudge' this attitude of concern towards actual behavior (Thaler and Sunstein 2008; Barr and Prillwitz 2014). In response to these attempts that try to determine mechanisms of sustainable behavior, Anders would argue that in contemporary times, examining whether people care or not is futile. In an age where people cannot be responsible for their own actions, 'care' is an irrelevant indicator for human behavior, regardless of whether they are acting as consumers or as citizens.

Moreover, as opposed to the notion of the ethically concerned consumer, ${ }^{18}$ Anders would claim that a couldn't-care-less attitude is determining the behavior of the contemporary human. This is not because we lost all our morals, but due to our attempts to hide the shame for not being responsible for our actions, ${ }^{19}$ the shame about our shame. Having feelings of inferiority towards our machines, we are hiding our shame behind gestures of concealment; in order to fool others but also ourselves. Taking up a couldn't-care-less-attitude is a likely strategy here, as it stands in opposition to shame. Shame is invisible as long as it is covered with confidence: 'The one who is not hiding, who keeps visible, is not under the suspicion of shame - and therefore stigma (Anders 1961, 29).

Thus, in the face of climate change, nominating ethical consumerism to a savior perfectly fits into the concept of concealment; we can comfort ourselves in maintaining the means of production and consumption, which we learnt to take as a given. Any attempts to change patterns related to these means would put us at risk to humiliate ourselves. Hence, as long as we produce and consume with the confidence of doing something good, we do not get into the shameful situation of being forced to confess that there might be something faulty about the system we are living in, of which we are responsible for while we are not.

\section{The moral schizophrenia of the citizen-consumer}

\footnotetext{
18 'Alternative', 'ethical', 'critical', 'radical' or 'political' consumption typically implies a notion that critically questions the contemporary consumption patterns such as in particular over-consumption, less in a sense of a renunciation of consumption, but more as active political participation through the marketplace (Sassatelli 2007, 186-188).

${ }^{19}$ Anders explains that the identity crisis of the human being is strongly related to shame. In the given situation, humans are forced to identify themselves with something that is part of them, even though they cannot identify themselves with it. Thus, humans are not ashamed even though it is not their fault, but because it is not their fault. They cannot deal with the contradiction, and they can also not deal with their shame (Anders 1961, 69).
} 
How do we know that we have reached the end of sustainability? Anders would answer this question by saying that we know it when supporting 'sustainable economic growth' appears to be the morally legitimate way to commit to sustainable development.

In 'The Obsolescence of Human Beings', Anders describes a society in which consciousness was replaced with conscientiousness. Anders identifies enterprises as institutions in which people are expected to join the given processes with one hundred percent and so are the birthplaces of the conformist (Anders 1961, 289-291). ${ }^{20}$ No matter whether individuals know what they are doing or not - there is no consciousness required for it, as product and production, morally speaking, are torn apart: 'The moral status of a product does not cast a shadow on the moral status of the one who works and therefore participates in its production. No matter whether he knows or does not know, what he is doing; he does not need a consciousness for what he is doing.' (Anders 1961, 289) And so we do welcome ideas on sustainable development today and try to make the 'right choices' in the supermarket. And it is not even difficult. In fact, one would struggle to find a company that does not claim to favour a sustainable economy.

Today's citizen-consumers show conscientiousness in relation to sustainable development, when they are in fact supporters of the current system and the market economy. We have learnt not to question taking historical progress and growth as the substrate of humanity (Anders 1961, 277-278). To a wide extent, we cannot even imagine to scrutinise our current system: A world without economic growth exceeds our imaginative power - we are blind to it. Defining sustainable development in a way that leaves the primacy of markets untouched, we bring evidence to our blindness. 'No situation is more evil than the one in which the evil became such an integral part of the situation that the individual can spare to be the evil $(1981,88),{ }^{21}$ as Anders put it once.

So why is it that we still hold on so strongly to a language around responsibility? Why do we not let go of the ideas raised by the environmental movement of the early 80 s, whose critique was mainly concerned with corporations in a way that has not got much in common with the ideals of a sustainable development today? Why do we speak about the ethical, political and emancipated consumers? A look at Anders' analysis of the situation of the workers in the age of the Second Industrial Revolution can explain this. While being expected to demonstrate conscientiousness by

\footnotetext{
20 'Every epoch gets the prophets it deserves (Anders 1964).'

${ }^{21}$ In that effect, Anders explains how for NS war criminals their actions were morally right. Back then, it was morally legitimate to take part in the operations of a death camp. The circumstances changed and moral legitimation shifted after the war, but back then, they did not act very different to what they were committed to by work organization (Anders 1961, 287-288). 'As long as we do not face the fact and do not realize that contemporary enterprises are the forge, the modus operandi and the prototype of gleichschaltung, we will remain incapable to understand the figure of the conformist. We will remain incapable to understand what it is all about the obdurate men who refused to regret or take the responsibility for co-conducting in atrocities.' The atrocities were not 'erratic incidences' of history that only happened once will ever happen again (Anders 1961, 290)
} 
showing a sense of duty for the system they are operating in on the one hand, they are, on the other, expected to be absolutely themselves in what they do outside of their working life. They are, for Anders, caught in a moral dilemma (Anders 1961, 291).

It can be said that the impossibility of balancing between compliance and emancipation reveals the schizophrenic character of the citizen-consumer that is in no way less schizophrenic than the character of the modern factory workers. For the latter, Anders claimed, there is no such thing as a sphere outside of the enterprise, because all crucial tasks are done inside the enterprise. Expected to embody two different types of being, a conformist in work and a non-conformist in private, the worker remains indolent; they expect a continuation of the process that is beyond their responsibility. Their own actions, however, are limited and are not involving any planning for time periods (Anders 1961, 291-294).

It is within his 'philosophical considerations on radio and television' (Anders 1961, 97-212) when Anders elaborates on how consumption is a force, in particular in the way it replaces leisure and manifests in daily life. The force to consume elides the world outside of the system of production. Leisure time, as opposed to working time, does not exist anymore as such; it is an inbuilt and necessary component to maintain the system. Thus, being given a 'choice' can be subjectively perceived as freedom but this is bound to the force of consumption, which is just another aspect of the force of production (Ribolits 1997).

Defining 'boycott' and 'buycott' as the common means of political participation, indeed, every individual can join in and do their part for a better world at any time, if they want to - by voting with their money. Facing the decline of gatherings, formations and social movements, shopping for the good cause became the new and defining type of political engagement, participation and change (Micheletti, Stolle and Berlin 2012). The 'shopping for change' paradigm demands us to be responsible individuals that consider complex social and environmental problems and develop own values and norms. The means to express this responsibility, however, are limited to the market - a system so deeply ingrained that we are blind to the restrictions it imposes on us.

Ethical consumerism reproduces the assumption that the consumer is the key agent for social change (Barnett et al. 2005). Ethical consumers are informed, reflexive and emancipated when they exercise choice and thereby pick the products that, as they have been told, are the 'right choice'. The paradigm of the informed and emancipated consumer creates the idea of individual freedom; a freedom whose limitation to economic liberalism we are blind to realize. It is the one we are used to, as the classical market theory taught us that 'the market is a democracy where every penny gives the right to vote' (Frank Fetter quoted in Dickinson and Carsky 2005, 25). However, '... the fact that the 
lack of freedom appears natural to us, that we do not notice the lack of freedom or, should we notice it, we do so tranquilly and with equanimity, does not make the situation any less disastrous. To the contrary: since the terror is delivered in the form of a thousand little cuts and eliminates imagination of a possible alternative situation, or any idea of opposition, it is in a way more fatal than any recognisable deprivation of liberty ' (Anders 1961, 198). Therefore, consumer choice, which promises to give us freedom within consumerism (Slater 1997), functions as a powerful tool to maintain our blindness. To quote Anders: 'no type of disempowerment of individuals is more successful than the one that seemingly safeguards their freedom' (Anders 1961, 104).

\section{Combating future-blindness - learning to predict the after}

The term 'sustainability' originated in the forest management of the early eighteenth century. In 1713, mining administrator Carl von Carlowitz published 'Sylvicultura Oeconomica' in which he argued that a continuously stable and sustainable utilization of forests was demanded (Ott and Döring, 2004). Thus, it was in reaction to a period of crisis and scarcity caused by the mining industry's immensely increased demand of wood that had consumed whole forests, that the term 'sustainability' was used for the first time. Thus, the concept of sustainability came up in reaction to

a development in which long-termism was replaced with short-termist profitability and the utilization of resources increased exponentially.

In the 1980s, the term was revisited and the ecological focus was expanded to economic and social aspects. Sustainability initially held strong links to environmental movements that acknowledged limitations of growth and advocated for an awareness of the resource-intensity of western lifestyles. However, the inclusion of 'development' gave way to a conceptualisation of sustainability that is adapted to the conditions it was intended to combat. Sustainability, consequently, remains an ideological promise to make some green technological adaptations while carrying on as usual. As such, it becomes apparent that the apocalyptical blindness that Anders attested 60 years ago in relation to the nuclear threat has been equally manifested in relation to the threat coming along with the resource consumption of today.

The launch of Sustainable Development Goals, yet again, demonstrates how apocalyptical blindness bears upon future-related blindness. The bourgeois belief in progress, Anders argues, makes humans future-blind. Having been transformed into beings forced to use the machines we produced, we accept the situation as a given: It is the only possible scenario of the world that we can imagine for us and we take it with enthusiasm. Certain questions about practices do not - indeed cannot - even come up, because the technologies determine what we have to want (Liessmann 2002, 156). Short- 
sighted, we run into the world of progress, while the horizon of the future, or what we could grasp from it, remains provincially narrow (Anders 1961, 282-284).

We are 'inverted utopists'. While utopists are incapable of creating what they imagine, we are incapable of imagining what we created (Anders 1981, 96). We are so habituated to this state that we are able to content ourselves with actions such as ethical consumption. We know about the interconnectedness of societal and environmental issues and we do 'our bit' when we make informed choices as consumers, or so we tell ourselves. Corporations do their bit too, because they enable the individual to make these informed choices. Protected by the 'alibi of the alleged knowledge' we can seclude ourselves in our state of not knowing (Anders 1961, 270).

As such, the promethean gap between knowledge and comprehension becomes ever more obvious. Concepts like sustainable development and ethical consumption focus on the knowledge that humans need to keep up with the requirements of the market and with its innovations. For Anders, however, the key lies in the in the comprehension of technological developments in relation to the self-perception of humanity. Thus, Anders demands that we have to learn to interpret technological developments in relation to ourselves as well as that we have to identify ourselves in relation to the world we are living in. We have to overcome the fact that our spiritual state at any given time only ever reflects the technical state of the past. That means we have to move on to a 'prognostic interpretation' (Anders 2002, 428).

This does not mean a sole fascination with the future though, for Anders it rests on our ability to overcome our concept of time: 'Time should not lie ahead of us, but captured by us, with us', in our presence' (Anders 1961, 284). That is, technology needs to be integrated into the self-interpretation of humanity rather than humanity integrated into technology. This is a moral task to all of us: '(I)f it is our fate to live in a (self-created) world of excess that eludes from our imaginations and feelings and in this way endangers us fatally, then we have to try to catch up with this excess.' (Anders 1961, 274) Thus, '...we have to learn to do what the seers of antiquity did (or were convinced they were doing): predict the future. The guts that we have to learn how to read as prognostic signs are not those of sacrificial animals, but those of machines. The machines reveal the world of the future to us and what our grandchildren will be like, provided they will exist. And if they will not do this themselves, we have to force them to do it.' (Anders 2002, 428)

The Prussian educational reformer Wilhelm von Humboldt once stated that it should be the ultimate purpose of the human entity to enable ourselves to grasp as much of our world as possible and to connect with it as close as we can; to become free from immaturity, self-confident, emancipated and to actively take part in our environment and community; in short: to stand in interaction to the 
world around us (von Humboldt 1980). In that sense, Anders end-time philosophy has rightly been interpreted as humanistic and educational, rather than apocalyptic (Bahr, 2012). Having reached the last epoch of humanity, increasing our ability to imagine our productive capacity is, according to Anders, the only way to interrupt the course towards the doom that threatens us (Anders 2002, 428429). The knowledge to use or consume the products that we produced and to adapt to the institutions we created has to be accompanied by a comprehension of ourselves in our world.

\section{Conclusion}

'Our end of the world is sung from the rooftops even by sparrows; the element of surprise is missing; it seems only a question of time.'

- Hans Magnus Enzensberger $(1978,75)$

We have written this article with the feeling and opinion that some aspects of Anders' work are vital to an historical understanding of the $21^{\text {st }}$ century and in particular, anthropogenic climate change and catastrophe. In the debate on options for political and personal action for sustainable development, Anders' cultural critique has been long required.

The 1950s, if they are thought of at all, are remembered as a time of technological optimism and Vorsprung durch Technik. Keynesian economic growth and technological prowess promised electricity too cheap to meter, the obsolescence of work and the notion of 'holidays on the moon' Anders was an early voice warning that this moment would not last. Many people reading this article will still be alive in 2050. Our visions for that time are bleaker - acidified oceans, scorched land, drowned cities and relentless extreme weather events. In 100 years, a geological blink of an eye, we will have passed from Promethean power to powerlessness, from control to contingency. Voices like Anders deserve to be heard as we chart an uncertain path.

Uncertainty, passivity and denial - these are themes drawn out across this special issue and things we have sought to address in this article; highlighting the value of Anders' work on these themes. In particular, why do we not act? How are we able to think but not feel? Why are we, as Paul Gilroy $(2012,391)$ argues, 'zombies...who exist in the context of a neo-liberal order that thrives on the brutal division of the world into two great teams: winners and losers.' Anders' philosophical anthropology dealt with these issues at length. In particular, the 'pluralisation' or 'splitting' of man. Humanity is not a single headed object, but 'a pair of men; the individual (who, as a metaphysical self-made man, had fought a Promethean struggle against the Gods) has now been replaced by men who fight each other for domination' (Anders 1965, 149). The sustainable development paradigm has reinforced this pairing; we fight each other for domination, for control and for power. 
For decades, one of the most widespread arguments from environmental groups has been the uneven ecological and social consequences of climate change; how poor nations and groups are to suffer first. As such, the apocalyptic vision of catastrophic climate change is not 'a bolt from the blue' but 'insidious and torturingly slow in its approach, the apocalypse in slow motion' (Enzensberger, $1978,75)$. The apocalypse of catastrophic climate change has itself been subject to division, plurality and machination; each part a section that can be fixed in itself - planetary climate change moves forward not as a whole but as fragments of destruction and annihilation.

And here we come back to Anders' (not Sartre's) notion that we humans are 'condemned to freedom'. We are free to engage in the world economy and sustainable development but under specific rules. Nations and groups at risk of climate change, also at risk of becoming losers in the global economic for sustainable development, can supposedly become winners. They can play the game, they are free to choose, but they are condemned to that freedom under particular rules and laws. The first law we can establish of this game is: there will be winners and losers.

In order to overcome this dialectic between winners and losers, master and slave, proletariat and bourgeoisie, Anders offers us some suggestions in order for us to 'catch up' with our creations. Catching up is very different from 'reconnecting' or 'realigning' or other such 're's' that have dominated narratives on how to develop a more sustainable world such as 'reconnecting with nature' or 'realigning our values'. Anders is not a conservative, or someone who believes in a romanticised past of pre-technological innovation, rather he sees technology and machines as overtaking us, and we need to move forward, not backwards.

In a remarkable series of letters between Günther Anders and Claude Eatherly, a pilot of a scout plane during the Hiroshima bombing, we are offered a rare moment of instrumentalism and succinctness from Anders $(1962,11-15)$ in a section titled 'Commandments in an Atomic Age' that we still find applicable today. We will leave you with these.

'First Thought: Atom

(The world around us is not stable.)

Second Thought: The possibility of the apocalypse is our work. But we know not what we are doing.

(The gap between action and imagination.)

Third Thought: 'Widen your sense of time.'

(Stretch your moral fantasy.)

Fourth Thought: 'Don't be a coward.' 
(It is our business, it is our turn to worry, we are equally incompetent.)' 


\section{Acknowledgments}

We would like to thank both reviewers Nina Isabella Moeller and John Martin Pedersen for their positive and enriching comments on the paper. Their helpful remarks led to a great improvement of the work, in particular in terms of language and clarity. Thanks also to Joachim Gruber, Abdulla Adel and Chloe Jeffries for their constructive comments on this article. 


\section{References}

Anders (Stern), G. 1950. "Emotion and Reality." Philosophy and Phenomenological Research 10 (4): $553-$ 562 http://www.guenther-anders-gesellschaft.org/wp-content/uploads/2014/01/Anders-Emotionand-Reality.pdf

Anders, Günther. 1961. Die Antiquiertheit des Menschen. Band I: Über die Seele im Zeitalter der zweiten industriellen Revolution. Munich: C.H. Beck.

Anders, Günther. 1964. Der sanfte Terror. Theorie des Konformismus. Merkur 18 (193): 209-224.

Anders, Günther. 1965. "Being Without Time: On Beckett's Play Waiting for Godot." In Samuel Beckett: A Collection of Critical Essays, edited by M. Esslin, Englewood Cliffs: Prentice-Hall.

Anders, Günther. 1981. Atomare Drohung. Radikale Überlegungen zum atomaren Zeitalter. Munich: C.H. Beck.

Anders, Günther. 2002. Die Antiquiertheit des Menschen. Band II: Über die Zerstörung des Lebens im Zeitalter der dritten industriellen Revolution. Munich: C.H. Beck.

Anders, Günther. 2009. "The Pathology of Freedom: An Essay on Non-Identification," translated by Katharine Wolfe, In Deleuze Studies 3 (2): 278-310.

Arendt, Hannah. 1963. Eichmann in Jerusalem. New York: Viking Press.

Bahr, Raimund. 2012. Günther Anders: Leben und Denken im Wort. Berlin: epubli.

Babich, Babette. 2012. "On Machines as the Masters of Humanity: Martin Heidegger, Günther Anders, and the Singularity of Digital Technology." Journal of the Hannah Arendt Center for Politics and Humanities at Bard College 2, 122-144.

Babich, Babette. 2013a. "Angels, the Space of Time, and Apocalyptic Blindness: On Günther Anders' Endzeit-Endtime." Ethics \& Politics 2: 144-174.

Babich, Babette. 2013b. “O, Superman! or Being Towards Transhumanism: Martin Heidegger, Günther Anders and Media Aesthetics." Divinatio: 83-99.

Barnett, Clive et al. 2011. Globalizing responsibility: The political rationalities of ethical consumption (RGSIBG book series). Chichester: Wiley-Blackwell.

Barr, Stewart and Prillwitz, Ann. 2014. "A smarter choice? Exploring the behaviour change agenda for environmentally sustainable mobility." Environment and Planning C 32 (1): 1-19.

Bataille, George. 1988. The Accursed Share: Volume 1. London: Zone Books.

Benjamin, Walter. 1969. Illuminations, edited with an Introduction by Hannah Arendt. Translated by Harry Zohn. New York: Schocken.

Benson, Melinda and Craig, Robin. 2014. "The End of Sustainability." Society \& Natural Resources: An International Journal, 27 (7): 777-782.

Blühdorn, Ingolfur. 2008. "Sustaining the Unsustainable: Symbolic Politics and the Politics of Simulation. Blühdorn, Ingolfur, and lan Welsh." In The Politics of Unsustainability: Eco-Politics in the PostEcologist Era. London: Routledge: 67-91.

Blühdorn, Ingolfur. 2011. "The Politics of Unsustainability: COP15, Post-Ecologism and the Ecological Paradox." Organization \& Environment 24 (1): 34-53.

Blühdorn, Ingolfur. 2015. "A much-needed renewal of environmentalism? Eco-politics in the Anthropocene." In The Anthropocene and the Global Environmental Crisis: Rethinking Modernity in a New Epoch, edited by C. Hamilton, F. Gemenne, and C. Bonneuil. London: Routledge: 156-167. 
Buell, Frederick. 2003. From Apocalypse to Way of Life: Environmental Crisis in the American Century, London: Routledge.

Cohen, Stanley. 2001. States of Denial: Knowing about Atrocities and Suffering. London: Polity Press.

Dawsey, Jason. 2012. "Where Hitler's Name is Never Spoken: Günther Anders in 1950s Vienna." In Austrian Lives (Contemporary Austrian Studies, Vol. XXI), edited by G. Bischof, F. Plasser and E. Maltschnig. New Orleans/Innsbruck: University of New Orleans Press/Innsbruck University Press: 212-239.

Dawsey, Jason. 2013. The limits of the human in the age of technological revolution: Günther Anders, postMarxism, and the emergence of technology critique, Dissertation, University of Chicago http://gradworks.umi.com/35/68/3568370.html

Death, Carl. 2015. "Disrupting Global Governance: Protest at Environmental Conferences from 1972 to 2012." Global Governance: A Review of Multilateralism and International Organizations 21 (4): 579598

Dickinson, Roger and Carsky, Mary. 2005. "The consumer as economic voter." In The ethical consumer, edited by R. Harrison, T. Newholm and D.Shaw, Thousand Oaks, CA: Sage.

Dries, Christian. 2014. "Vita Günther anders (1902-1992). Internationale Günther Anders Gesellschaft." http://www.guenther-anders-gesellschaft.org/vita-guenther-anders/

Eatherly, Claude. 1961, Burning Conscience: The case of the Hiroshima pilot, Claude Eatherly, told in his letters to Günther Anders, New York: Monthly Review Press.

Enzensberger, Hans, Magnus. 1978. "Two Notes on the End of the World." New Left Review, July-August: 74-80.

Foster, John. 2015. After sustainability: Denial, hope, retrieval. Abingdon, Oxon, New York: Routledge.

Gehlen, Arnold. 1940. Der Mensch, seine Natur und seine Stellung in der Welt. Berlin: Junker \& Dünnhaupt.

Gilroy, Paul. 2012. "'My Britain is Fuck All' Zombie Multiculturalism and the Race Politics of Citizenship." Identities: Global Studies in Culture and Power, 19 (4): 380-397.

Greffrath, Mathias. 1989. "'Wenn ich verzweifelt bin, was geht's mich an?' Gespräch mit Günther Anders.” In Die Zerstörung einer Zukunft - Gespräche mit emigrierten Sozialwissenschaftlern, edited by M. Greffrath, Frankfurt am Main: Campus: 17-55.

Heffernan, Margaret. 2011. Wilful Blindness: Why We Ignore the Obvious at our Peril. New York: Simon and Schuster.

Heidegger, Martin. 1976. "Nur noch ein Gott kann uns retten," Der Spiegel 30 (Mai, 1976): 193-219, trans. by W. Richardson as "Only a God Can Save Us" In Heidegger: The Man and the Thinker (1981), edited by T. Sheehan: 45-67.

Howe, Joshua. 2014. Behind the Curve: Science and the Politics of Global Warming. Seattle: University of Washington Press.

Libcom.org. 2014. The obsolescence of man, vol I , part 2: The world as phantom and as matrix: philosophical considerations on radio and television https://libcom.org/library/obsolescence-manvolume-i-part-two-\%E2\%80\%9C-world-phantom-matrix-philosophical-considerations-r

Libcom.org. 2015. The obsolescence of man - Volume 2 https://libcom.org/library/obsolescence-manvolume-2-g\%C3\%BCnther-anders

Liessmann, Konrad Paul. 2002. Günther Anders: philosophieren im Zeitalter der technologischen Revolutionen. München: C.H. Beck. 
Liessmann, Konrad Paul. 2011. "Thought after Auschwitz and Hiroshima: Günther Anders and Hannah Arendt." Enrahonar, 46: 123-135.

Micheletti, Michelle; Stolle, Dietlind and Berlin, Daniel. 2012. "Habits of Sustainable Citizenship: The Example of Political Consumerism." In The Habits of Consumption, edited by A. Warde and D. Southerton, Helsinki: Helsinki Collegium for Advanced Studies: 141-163.

Müller, Christopher. 2015. "Desert Ethics: Technology and the Question of Evil in Günther Anders and Jacques Derrida." Parralax, 21:1, 42-57.

Moon, Ban-Ki. 2015. Secretary-General's remarks at the United Nations Private Sector Forum New York, 26 September. http://www.un.org/sg/statements/index.asp?nid=9020

Mumford, Lewis. 1957. The Transformations of Man, London: G. Allen \& Unwin.

Nietzsche, Frederick. 1907. Beyond good and evil, translation by Helen Zimmern, New York: Macmillan.

Ott, Konrad and Döring, Ralf. 2004. Theorie und Praxis starker Nachhaltigkeit, Marburg: Metropolis.

Popper, Karl. 1957. The Poverty of Historicism. London: Routledge.

Ribolits, Erich 1997. Die Arbeit hoch? Munich: Profil.

Sartre, Jean-Paul. 1939. Sketch for a Theory of the Emotions, London: Routledge.

Sartre, Jean-Paul. 2003. Being and Nothingness: An Essay on Phenomenological Ontology. Abingdon: Routledge, Routledge Classics.

Sassatelli, Roberta. 2007. Consumer culture: History, theory and politics. Los Angeles: Sage Publications.

Schraube, Ernst. 2005. "Torturing Things Until They Confess': Günther Anders' Critique of Technology." Science as Culture 14 (1): 77-85.

Slater, Don. 1997. Consumer Culture and Modernity. Cambridge, UK: Polity Press.

Spash, Clive. 2016. "This Changes Nothing: The Paris Agreement to Ignore Reality." Globalizations: 1-6.

Thaler, Richard. and Sunstein, Cass. 2008. Nudge: Improving Decisions about Health, Wealth and Happiness. Yale: Yale University Press.

Trentmann, Frank. 2007. "Introduction: Citizenship and Consumption." Journal of Consumer Culture, 7 (2): 147-158.

United Nations. 1987. Our Common Future - Brundtland Report. Oxford: Oxford University Press.

United Nations. 2015. Transforming our World: The 2030 Agenda for Sustainable Development. http://www.un.org/pga/wp-content/uploads/sites/3/2015/08/120815 outcome-document-ofSummit-for-adoption-of-the-post-2015-development-agenda.pdf

Van Dijk, Paul. 2000. Anthropology in the Age of Technology: The Philosophical Contributions of Günther Anders. Amsterdam: Rodopi, 2000.

von Humboldt, W. 1980. "Theorie der Bildung des Menschen." In Wilhelm von Humboldt. Werke in fünf Bänden, Bd 1., edited by A. Flitner and K. Giel. Darmstadt: Wissenschaftliche Buchgesellschaft: 234240.

Webber, Jonathan. 2010. Reading Sartre: On Phenomenology and Existentialism. London: Routledge.

Young, Michael. \& Jessica Barr. 2014. "(Mis)reading Revelations: Apocalyptic Visions and Environmental Crisis \& Augury: Elegy." UnderCurrents: Journal of Critical Environmental Studies 18: 7-17. 